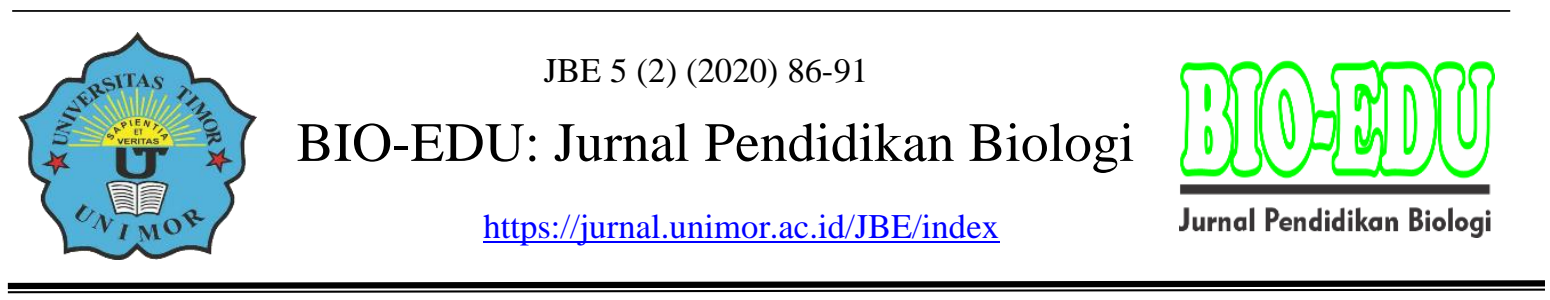

\title{
Dekomposisi Hemiselulosa Sekam Padi Oryza sativa L Oleh Jamur Pelapuk Kayu
}

\author{
Welsiliana \\ Program Studi Biologi, Fakultas Pertanian, Universitas Timor, Kefamenanu \\ Email:welsiliana@unimor.ac.id
}

DOI: $\underline{\text { https://doi.org/10.32938/jbe.v5i2.571 }}$

\begin{abstract}
Abstrak
Penelitian ini bertujuan untuk mengetahui pertumbuhan dan kemampuan dekomposisi jamur pelapuk kayu dalam menurunkan hemiselulosa. Penelitian menggunakan tujuh isolat jamur pelapuk kayu yang diinokulasikan ke dalam substrat organik dan diinkubasi selama 30 hari. Jamur yang ada pada substrat organik diamati pertumbuhannya dan dianalisis penurunan kadar hemiselulosanya menggunakan metode Van Soest. Hasil penelitian menunjukkan pertumbuhan isolat jamur yang paling cepat telihat pada isolat JM yang memenuhi seluruh substrat organik kemudian berturut-turut isolat MKS, KSH, B, KSB, E dan C. Dekomposisi hemiselulosa yang terbesar diperoleh dari isolat MKS yaitu $79.69 \%$.
\end{abstract}

Kata kunci: Dekomposisi, hemiselulosa, jamur pelapuk, Oryza sativa L

\begin{abstract}
The objective of this study was to investigate the growth and decomposition ability of wood rot fungi in reducing of hemicellulose. The study used seven fungal isolates of wood rot fungi which were inoculated into organic substrate and incubated for 30 days. The growth of fungi on the organic substrate was observed and the decrease level of hemicellulose by using the Van Soest method was analyzed. The results showed that the fastest growth of fungal isolates was seen in JM isolates that filled all organic substrates and then MKS, $\mathrm{KSH}, \mathrm{B}, \mathrm{KSB}, \mathrm{E}$ and $\mathrm{C}$ isolates. The most effective hemicellulose decomposition was obtained from MKS isolates which was $79.69 \%$.
\end{abstract}

Keywords: Decomposition, hemicellulose, wood rot fungi, Oryza sativa L

\section{PENDAHULUAN}

Produksi padi di Indonesia yang cukup besar, memunculkan sebuah masalah baru yaitu berlimpahnya limbah pertanian berupa sekam padi. Sekam padi keberadaannya cendrung meningkat namun mengalami proses penghancuran secara alami berlangsung lambat, sehingga dapat mengganggu lingkungan juga kesehatan manusia. Cara yang biasa dipergunakan untuk membuang sekam adalah membakarnya di tempat terbuka. Aktifitas yang sering dilakukan ini akan mengakibatkan pencemaran lingkungan emisi gas (Harsono, 2002).

Pengolahan sekam padi sangatlah terbatas karena massa jenisnya yang rendah, dekomposisi secara alami sangat lambat dan dapat menimbulkan penyakit pada tanaman 
padi maupun tanaman lain. Proses dekomposisi ini mempunyai prinsip dasar yaitu menurunkan komponen-komponen yang terkandung dalam bahan organik secara terkontrol menjadi bahan anorganik.

Alternatif inovasi teknologi dalam memaksimalkan limbah sekam padi sangat perlu dilakukan karena akan memberikan manfaat yang lebih besar. Salah satu pengelolaan limbah organik sekam padi adalah pengelolaan secara biologis dengan menggunakan jamur pelapuk. Bahan-bahan organik seperti selulosa, hemiselulosa dan lignin didekomposisi oleh mikroorganisme ini. Penelitian ini berfokus pada salah satu penyusun lignoselulosa saja yaitu hemiselulosa, karena telah dilakukan peneltian sebelumnya dan hasil yang diberikan adalah hemiselulosa paling cepat terdekomposisi dibandingkan dengan selulosa dan lignin. Hemiselulosa merupakan polisakarida terbanyak kedua setelah selulosa. Komponen polisakaridanya baik yang linier maupun bercabang banyak ditemukan sebagai heteroglikan pada tumbuhan tingkat tinggi (Saha, 2003). Berdasarkan komposisi gulanya, hemiselulosa diklasifikasikan sebagai xilan, manan, arabinogalaktan dan arabinan. Hemiselulosa bersama-sama dengan selulosa dan lignin merupakan komponen terbesar penyusun struktur dinding sel tumbuhan.

Hasil akhir yang diharapkan dengan adanya jamur pelapuk sebagai agen dekomposer biologis akan memberikan dampak yang menguntungkan masyarakat khususnya dibidang pertanian. Selain pengurangan limbah sekam dapat dilakukan, prospek kedepan yaitu dihasilkannya pupuk hayati dari hasil dekomposisi sekam padi dan hal inilah yang melatarbelakangi dilakukannya penelitian ini.

\section{METODE}

Isolat jamur yang digunakan yaitu isolat jamur pelapuk kayu koleksi Laboratorium Bioteknologi Pusat Kegiatan Penelitian (PKP), Universitas Hasanuddin, Makassar. Koloni jamur yang ada pada media agar dipotong dengan ukuran $1 \mathrm{~cm}$ x 1 $\mathrm{cm}$, sebanyak 5 potongan dimasukkan ke dalam plastik yang berisi sekam padi. Media sekam padi yang sudah diinokulasi dengan jamur diinkubasi dan dilakukan pengamatan pertumbuhan koloni jamur setiap selang waktu 3 hari selama 30 hari.

Pengukuran kadar penurunan hemiselulosa sekam padi ditentukan dengan menghitung kadar ADF (Acid Detergent Fiber) dan NDF (Neutral Detergent Fiber) menggunakan metode Van Soest (Van Soest, 1976).

\section{HASIL DAN PEMBAHASAN}

\section{Isolat Jamur Pelapuk Kayu}

Isolat jamur pelapuk yang digunakan pada penelitian ini terdiri atas 7 isolat. Isolat-isolat tersebut telah diseleksi sehingga memiliki potensi yang baik dalam menguraikan senyawa-senyawa organik. Gambar 1 menunjukkan isolat jamur pelapuk terdiri atas jamur pelapuk putih dan jamur pelapuk coklat. Kedua jamur pelapuk ini tergolong kedalam kelompok basidiomisetes. Jamur pelapuk coklat memiliki kemampuan enzimatis melapukkan kayu dengan cara menyerang holoselulosa (selulosa dan hemiselulosa). Sedangkan jamur pelapuk putih mendekomposisi lignin dan polisakarida (lignin dan hemiselulosa) (Eaton dan Hale, 1993). 


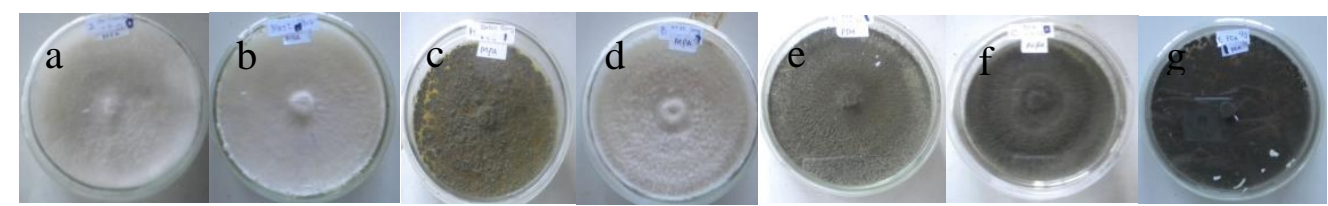

Gambar 1. Isolat jamur pelapuk kayu: (a) JM, (b) MKS, (c) E, (d) KSB, (e) KSH, (f) B dan (g) C

\section{Pertumbuhan Isolat Jamur pada Media Organik}

Hasil pengamatan pertumbuhan jamur pelapuk kayu pada media sekam padi menunjukkan pertumbuhan yang berbeda-beda (Tabel 1). Pengamatan pertama yaitu 3 hari setelah isolat jamur diinokulasi ke dalam media organik, menunjukkan bahwa sudah nampak pertumbuhan miselum jamur tetapi pertumbuhannya belum memenuhi seluruh substrat organik. Hari ke-30 setelah inokulasi, pertumbuhan jamur di media organik sudah banyak. Parameter yang menunjukkan banyaknya miselium jamur yang tumbuh yaitu perubahan warna pada subtrat yang lama kelamaan berubah sesuai dengan warna isolat jamur yang diinokulasikan.

Tabel 1 menunjukkan isolat JM adalah isolat yang pertumbuhan miseliumnya paling cepat. Pertumbuhan miselium jamur tersebut memenuhi seluruh substrat organik yang ada di permukaan sampai ke dasar media. Isolat MKS dan KSH merupakan isolat yang hampir sama dengan isolat JM yaitu pertumbuhan miselium jamur telah memenuhi substrat organik tetapi koloni jamurnya masih belum terlalu banyak. Penelitian ini hanya menggunakan hasil peremajaan isolat yang tumbuh diatas media agar sehingga inokulan yang dimasukkan ke dalam media organik tidak merata. Menurut Herliyana (2007) inokulan dalam bentuk cair lebih efektif daripada bentuk padat karena pertumbuhan miselium jamur akan lebih cepat memenuhi seluruh substrat organik.

Isolat jamur B, KSB, E dan C menunjukkan pertumbuhan yang sangat lambat seperti yang terlihat pada Tabel 1 . Isolat $\mathrm{E}$ hanya memiliki pertumbuhan koloni jamur pada bagian dasar media sedangkan isolat $\mathrm{C}$ memiliki pertumbuhan dibagian permukaan, hal yang sama dengan isolat KSB dan isolat B. Kemampuan pertumbuhan tiap-tiap isolat berbeda dalam memanfaatkan substrat organik sebagai sumber nutrisi. Selain itu, kadar air pada media organik juga berperan penting sebagai pengencer agar miselia jamur dapat tumbuh maksimal dan proses penyerapan makanan dari media / substrat lebih cepat. Proses penyerapan nutrisi akan mempengaruhi pertumbuhan jamur sehingga dihasilkan miselium yang banyak (Yuniasmara dkk, 2004).

\section{Tabel 1. Pertumbuhan isolat jamur pada sekam padi setelah 3 dan 30 hari inkubasi}

\begin{tabular}{lcccc}
\hline & \multicolumn{2}{c}{ Hari ke-3 } & \multicolumn{2}{c}{ Hari ke-30 } \\
\cline { 2 - 5 } \multicolumn{1}{c}{ Perlakuan } & $\begin{array}{c}\text { Warna } \\
\text { miselium }\end{array}$ & Pertumbuhan & $\begin{array}{c}\text { Warna } \\
\text { miselium }\end{array}$ & Pertumbuhan \\
\hline Kontrol & - & & - & - \\
Isolat JM & Putih & - & Putih & ++ \\
Isolat MKS & Putih & + & Putih & ++ \\
Isolat KSH & Hijau & + & Hijau & ++ \\
Isolat B & Hijau & + & Hijau & + \\
Isolat KSB & Putih & + & Putih & + \\
\hline
\end{tabular}

88|WeIsiliana/JBE 5 ( 2) ( $\left.\begin{array}{lll}2 & 0 & 2\end{array}\right) \quad 86-91$ 


\begin{tabular}{lllll}
\hline Isolat E & Hitam & + & Hitam & + \\
Isolat C & Hijau & + & Hijau & + \\
\hline C & & &
\end{tabular}

Catatan:

$+++=$ Miselium jamur yang memenuhi seluruh substrat

$++=$ Miselium jamur yang memenuhi hampir seluruh substrat

$+\quad=$ Miselium jamur yang hanya memenuhi sebagian substrat

Pertumbuhan jamur dipengaruhi oleh berbagai faktor, salah satunya adalah suhu. Namun, toleransi terhadap suhu akan bervariasi antara genus bahkan antara isolat. Faktor-faktor penting lainnya yang mempengaruhi pertumbuhan jamur adalah sumber karbon, nitrogen, pH, makronutrien dan mikronutrien. Faktor eksternal tersebut paling sering ditemukan adalah kandungan nitrogen yang melimpah dalam suatu substrat organik.

Jamur pelapuk putih tumbuh pada substrat organik yang kandungan nitrogennya rendah. Kelebihan nitrogen pada substrat dapat menyebabkan terakumulasinya amonia yang dapat meningkatkan $\mathrm{pH}$ sehingga menghambat pertumbuhan miselium dan pembentukan tubuh buah (Stamets dan Chilton, 1983). Yuliastuti dan Susilo (2003) juga menyatakan bahwa jamur menggunakan nitrogen terutama dalam bentuk amonium sebagai pemasok $\mathrm{N}$ untuk pertumbuhannya, akan tetapi jumlah amonium bebas yang berlebih akan bersifat toksik sehingga menghambat pertumbuhan jamur tersebut.

\section{Analisis Penurunan Kandungan Hemiselulosa}

Analisis kandungan hemiselulosa menunjukkan bahwa tiap isolat memiliki kemampuan dekomposisi yang berbeda-beda (Gambar 2). Media organik yang diinokulasi isolat MKS mengalami penurunan hemiselulosa yang paling tinggi dibandingkan isolat lainnya yaitu $79.69 \%$. Sedangkan isolat yang penurunan kadar hemiselulosanya paling rendah terdapat pada isolat JM (39.47\%).

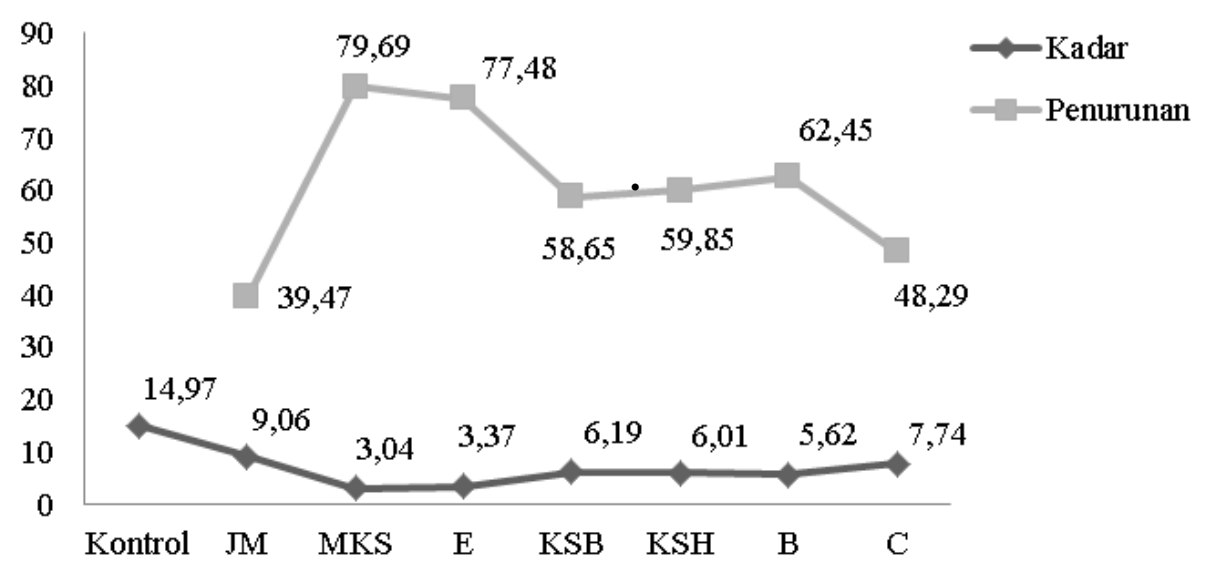

Gambar 2. Grafik penurunan kadar hemiselulosa, 30 hari setelah inokulasi.

Gambar 2 menunjukkan penurunan kadar hemiselulosa mencapai 80\%. Hadar dkk (1993) menyatakan bahwa jamur pelapuk putih mengeluarkan enzim hemiselulase dan untuk mendekomposisi hemiselulosa menjadi struktur yang lebih sederhana peranan enzim ini sangat penting. Enzim pendekomposisi hemiselulosa adalah kelompok enzim hemiselulase (Chang dan Miles, 1989). Gandjar dkk (2006) juga 
menyatakan enzim yang dihasilkan tiap jamur mempunyai kecepatan yang berbeda dalam mengubah substrat organik menjadi senyawa yang lebih sederhana. Hemiselulosa akan terdekomposisi menjadi produk yang mudah larut dalam air akibatnya kandungan hemiselulosa menurun, sedangkan kandungan isi sel akan meningkat (Krishaditersanto, 2018).

Hemiselulosa adalah komponen yang pertama terdekomposisi karena hemiselulosa strukturnya lebih sederhana dan terikat dengan polisakarida, protein dan lignin sehingga lebih muda larut dibandingkan dengan selulosa. (Anindyawati, 2009). Morrison (1986) menyatakan bahwa hemiselulosa juga relatif lebih mudah dihidrolisis dengan asam menjadi monomer yang mengandung glukosa, mannosa, galaktosa, xilosa dan arabinosa. Selain itu, apabila dibandingkan dengan komponen lignoselulosa lainnya (selulosa dan lignin) penurunan komponen hemiselulosa paling cepat terjadi karena hemiselulosa mempunyai berat molekul yang lebih rendah (Fitrianti, 2016).

\section{KESIMPULAN}

Berdasarkan hasil penelitian yang telah dilakukan, maka dapat disimpulkan bahwa :

1. Isolat jamur pelapuk kayu dapat tumbuh dalam substrat organik yaitu sekam padi. Tiap isolat memiliki kecepatan pertumbuhan yang berbeda dan isolat yang paling cepat tumbuh dan memenuhi seluruh substrat organik yaitu isolat JM.

2. Proses dekomposisi sekam padi oleh isolat jamur pelapuk kayu yang memperlihatkan penurunan komponen hemiselulosa dengan cepat adalah isolat MKS (79,69\%).

\section{DAFTAR RUJUKAN}

Anindyawati, T. (2009). Prospek Enzim dan Limbah Lignoselulosa untuk Produksi Bioetanol. BS, 1(44), $49-56$.

Chang, S.T., \& Miles, P.G. (1989). Edible mushrooms and their cultivation. Boca Raton, FL: CRC Pr.

Eaton, R.A., \& Hale, M.C.D. (1993). Wood Decay Pests and Protection. London, GB: Champman and Hall.

Fitrianti. (2016). Efektivitas Isolat Jamur Pelapuk dan Mikroorganisme Lokal dalam Menguraikan Limbah Kulit Kakao. Agrovital, 1(1), 9-11.

Gandjar, I., Wellyzar, S., \& Aryanti. (2006). Mikologi Dasar dan Terapan. Jakarta, ID: Yayasan Obor.

Hadar, Y., Kerem, Z., \& Gorodecki, B. (1993). Biodegradation of Lignocellulosic Agricultural Wastes by Pleurotus ostreatus. J Biotech, 30(1), 133 - 139.

Harsono, H. (2002). Pembuatan Silika Amorf dari Limbah Sekam Padi. Jurnal Ilmu Dasar, 3(98).

Herliyana, E.N. (2007). Potensi Ligninolitik Jamur Pelapuk Kayu Kelompok Pleurotus [Disertasi]. Bogor, ID: Sekolah Pasca Sarjana Institut Pertanian Bogor.

Krishaditersanto, R. (2018). Degradasi komponen serat serbuk gergaji hasil biokonversi jamur tiram putih (Pleurotus ostreatus) dengan level urea berbeda. Jurnal IlmuIlmu Peternakan, 28 (2), 175 - 182. 
Morrison, F.B. (1986). Feed and Feeding $21^{\text {th }}$ Ed. Iowa, IA: The Iowa State University Pr.

Saha, B.C. (2003). Hemicellulose Bioconversion. J Ind Microbiol Biotechnol, 30, 279 291.

Stamets, P., \& Chilton, J.S. (1983). The Mushroom Cultivator pp. 415. Washington DC, USA: Agaricon pr.

Van Soest, P.J. (1976). New Chemical Methods for Analysis of Forages for The Purpose of Predicting Nutritive Value. Pref IX International Grassland Cong.

Yuliastuti, E., \& Susilo, A. (2003). Studi Kandungan Nutrisi Limbah Media Tanam Jamur Tiram Putih (Pleurotus ostreatus) untuk Pakan Ternak Ruminansia. Jurnal Matematika, Saint dan Teknologi, 4(1), 54 - 61.

Yuniasmara, C., Muchrodji., \& Bakrun, M. (2004). Jamur Tiram. Jakarta, ID: Penebar Swadaya. 